EISSN: 2706-7939 ISSN: 2077-4508

DOI: $10.36632 / \mathrm{ije} / 2021.10 .1 .2$

Journal homepage: www.curresweb.com

Pages: 15-24

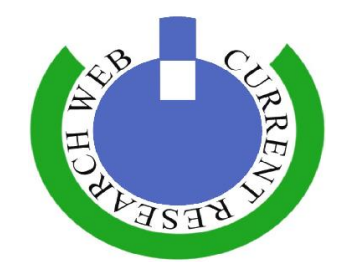

\title{
Cultivation and Production of Pleurotus Mushroom on Non-Traditional Growing Media
}

\author{
Ibrahim M. Gomaa ${ }^{1}$, Mahmoud I. Y. ${ }^{2}$ and Afifi M. M. I. ${ }^{2}$ \\ ${ }^{1}$ Environment and Bio-agriculture Department, Faculty of Agriculture, Al-Azhar University, Cairo, \\ Egypt \\ ${ }^{2}$ Soils, Water and Environment Research Institute, Agriculture Research Center, Giza, Egypt
}

Received: 15 December 2020 Accepted: 10 January $2021 \quad$ Published: 20 January 2021

\begin{abstract}
The study was carried out to evaluation different substrate as growing media for two different species of pleurotus (Pleurotus ostreatus and Pleurotus cystidiosu) on growth and yield of spawn and their contents from elements. Three substrates mixed with agar were used potato dextrose agar, vermicompost tea agar and compost tea agar for spawn production. The same substrates without agar (broth) in addition to, wheat seeds were used as control media for propagation of spawn on rice straw as traditional media for mushroom production. The results indicated that various substrate formulas gave significant differences in weight of spawn, growth speed rate, total yield on rice straw and its content of nourishes. Vermicompost tea as growing media was more efficient in spawn weights than other growing media with the both types of pleurotus. The highest yield was obtained when its spawn grown on rice straw (9.95 and $7.5 \mathrm{Kg}$ ) with both Pleurotus ostreatus and Pleurotus cystidiosus respectively. Total carbohydrates and energy were very high when Pleurotus ostreatus has grown on wheat seed (55.3 and $312.9 \mathrm{kcal} / 100 \mathrm{~g}$ respectively). Percentages of total protein, fat and ash were also high when it has grown on vermicompost tea (27.3, 2.3 and 6.85 respectively).Vermicompost tea achieved the greatest productivity and biological efficiency (156.25) and Pleurotus ostreatushas higher total yield and biological efficiency than Pleurotus cystidiosus.
\end{abstract}

Keywords: mushroom, pleurotus. vermicompost, compost, tea, biological efficiency

\section{Introduction}

Pleurotus spp. agronomy has increased extremely in the world during the last few years (Royse, 2002). Pleurotus mushroom are considering as $14.2 \%$ of the total world production of edible mushroom in 1997 (Chang, 1999). The fruiting body of the paddy straw mushroom is divided into six different developmental stages viz., pinhead, tiny button, button, egg, elongation and mature stage. Each stage has its own morphology and anatomy. Mushrooms were harvested when the mushroom cap surface were flat to slightly up-rolled at the cap margins. The harvested fruiting bodies in each bag were then counted and weighed. At the end of the harvest period, the accumulated data were used to calculate the biological efficiency and mushroom weight, (Pavlik, 2005).

Mushrooms are used as meat alternatives and flavorings. Edible mushrooms are low in fat and calories, rich in vitamin B and C, contain more protein than any other food of plant source. It is a good foundation of mineral nutrients (Bahl, 1998). Rates of protein mushrooms can differ from $10-40 \%$ of dry weight. It contains all the essential amino acids, (Chang, 1991). In addition, mushroom has important role in medical field, where some polysaccharides were extracted from spore and mycelium and has a role in antitumor dehydrated submerged liquid culture (Rahman et al., 2012). Mushrooms with their flavour, texture, nutritional value and high efficiency per unit area have been identified as an excellent nourishment source to improve malnutrition in developing countries (Eswaran and Ramabadran 2000). Pleurotus mushroom cultivation can play a vital role in management of organic wastes whose disposal 
has become a problem. Mushroom can use wide range of cellulosic materials and the $\mathrm{C}: \mathrm{N}$ ratio needed is about 40 to 60 , compared to other cultivated mushrooms. It can be grown quite quickly and easily on uncomposted substrates such as paddy straw and cotton waste or other cellulosic organic waste materials (Das and Mukherjee, 2007).

Compost and vermicompost tea contains high population of benefit microbes such as nitrogen fixers and phosphate solubilizes and also the secret growth regulators which have a role to enhance the growth and increase yield of different crops. Mushroom grow on different media such as compost and vermicompost which achieve the best significant yield potential and growth behavior with Pleurotus spp. (Sylvia, 2004; Antonio et al., 2008).

In Egypt, Mushroom production is stilling limited and is progressed slowly as compared to other countries in the world. The causes for slow progressive of mushroom are shortage of technically trained people, unsaved fixe source and trust to produce spawn. It exposed to damage during transport and storage processes and low researches in this filed. Egypt import high quantity with highly cost although, it has territories with the various temperature and weathers which are suitable for mushroom growth. The needing became argent to save the production of spawn with high quantity and low cost.

In the present study, two types of Pleurotus were growing in different media to achieve a significant medium for the best growth of mushroom with low cost to reduce the duration period of growth.

\section{Materials and Methods}

The experiment was carried out for the possibility to use different Pleurotus spp. for spawn production in Mushroom Unite in Faculty of Agriculture in Cairo, Al- Azhar University, Egypt.

\subsection{Mushroom Strains:}

Two different strains of pleurotus spp. (Pleurotus ostreatus and Pleurotus cystidiosus) were used for the observation of their growth and yield potential. Strains were kindly obtained from Agricultural Microbiology Dept., Soils, Water and Environment Research Institute (SWERI), Agricultural Research Center (ARC), Giza, Egypt.

2.1.1. Wheat grain and rice straw were kindly obtained from Filed Crops Institute, ARC, Giza, Egypt. Rice straw analysis is presented in Table (1)

Table 1: Chemical analysis in rice straw

\begin{tabular}{ccccccccccc}
\hline $\begin{array}{c}\text { Organic } \\
\text { matter } \\
\%\end{array}$ & $\begin{array}{c}\text { Organic } \\
\text { carbon } \\
\%\end{array}$ & $\begin{array}{c}\text { Ash } \\
\%\end{array}$ & $\begin{array}{c}\text { Carbon } \\
\text { Nitrogen } \\
\text { Ratio }\end{array}$ & $\begin{array}{c}\text { Total } \\
\text { Nitrogen } \\
\%\end{array}$ & $\begin{array}{c}\text { Total } \\
\text { Phosphorus } \\
\%\end{array}$ & $\begin{array}{c}\text { Total } \\
\text { Potassium } \\
\%\end{array}$ & $\begin{array}{c}\text { Fe } \\
(\mathbf{p p m})\end{array}$ & $\begin{array}{c}\text { Mn } \\
(\mathbf{p p m})\end{array}$ & $\begin{array}{c}\mathbf{Z n} \\
(\mathbf{p p m})\end{array}$ & $\begin{array}{c}\mathbf{C u} \\
(\mathbf{p p m})\end{array}$ \\
\hline 80.18 & 46.5 & 19.82 & $95: 1$ & 0.49 & 0.52 & 0.77 & 722 & 75 & 220 & 61 \\
\hline
\end{tabular}

2.1.2 Mother culture has completely good characteristic (size and shape) from Pleurotus spp. It was 24 hours old on petri dish contained potato dextrose media to produce white fungimycelium.

2.3. Spawn preparation: mother culture was inoculated on wheat grain after incubation period.

2.3.1. Compost and compost tea (CT) Preparation: compost was prepared from mixture of plant and animal wastes $(1: 1)$ for three months until mature phase. Compost tea was prepared from compost completely submerged the respective inside cotton bags with ratio of 1:5 and soaked for 10 days with aerated system and then amended with $0.5 \%(\mathrm{v} / \mathrm{v})$ molasses.

2.3.2. Vermicompost and vermicompost tea (VT) preparation: vermicompost was prepared from previous compost after finishing the thermophilic phase using Eisenia fetida worms for two months. Vermicompost tea was prepared according the method described by Shrestha et al., (2013). 


\subsection{Media preparation:}

2.4.1. Compost tea agar (CTA) and vermicompost tea agar (VTA) media: twenty gram agar $(20 \mathrm{~g} / \mathrm{L})$ were added to $250 \mathrm{ml}$ of CT or VT in Erlenmeyer flasks to prepare CTA or VTA media. The pH was adjusted at $\mathrm{pH} 7$ by diluted potassium hydroxide to the nutrient broth in both media then sterilized in autoclave $121^{\circ} \mathrm{C}$, for 20 minutes, (Stamets, 2005).

2.4.2. Potato dextrose agar media (PDA): Potato Infusion of $200 \mathrm{~g}$, Dextrose $20 \mathrm{~g}$ and agar $15 \mathrm{~g} / \mathrm{L}, \mathrm{pH}$ was adjusted to $5.6 \pm 0.2$ at $25^{\circ} \mathrm{C} .39 \mathrm{~g}$ of the medium were suspend in one liter of purified water, frequently agitated and boiled for one minute to completely dissolve, the medium was sterilized in autoclave at $121^{\circ} \mathrm{C}$ for 15 minutes (Vanderzant and Splittstoesser, 1992).

2.4.3. Liquid media inoculation: The liquid media of Potato dextrose (PD), vermicompost tea (VT) and compost tea $(\mathrm{CT})$ were inoculated with one disk from the primary grown mycelium to get fungi spawn.

\subsection{Procedures}

Good characterized (size and shape) of Pleurotus spp. (24 hours old), surface was washed with sodium hypochlorite $(0.5 \%)$ for 5 minutes (Booth 1971), submerged in distilled water for two minutes to remove the residue of sterilized solution and dry by filter paper (Stamets and Chilton, 1983). The cap was removed and the fungi stem was vertical cut off to cubic pieces by sterilized gift then submerged in sterilize central petri dish contents PDA media (Oei, 2003), incubated at $25 \mathrm{C}^{\circ}$ for 5 days, ten petri dishes were replicated for each strain. After fishing the incubation period, white fungi mycelium was appeared and measured its growth period, the fast growth called mother culture. Mother culture was cut down in to disks by cork borer, then inoculated one disk to each solid media CTA, VTA and PDA. Cooked wheat grain, compost and vermicompost of each solid media included five plastic bags and three replicate of each contented 500grams of solid media. The liquid media (PD, VT and CT) were inoculated with one disk from primary mycelium to get fungi spawn. Each treatment has five flasks $(1000 \mathrm{ml})$ with three replicates. Both solid and liquid media were incubated at $25 \mathrm{C}^{\circ}$. To produce spawn, wheat grain soaked in water for 24 hours for cleaning and removing broken and damaged seeds then submerged in boiling water for ten minutes, filtered and left to dry until the moisture content reached to $48-50 \%$ and fifteen gram of calcium carbonate, 10gram hydrate calcium sulfate were added to one kilogram of seeds on the bases of fresh weight and good mixed then. $400 \mathrm{~g}$ of the transported into poly ethylene bags closed and sterilized in autoclave at $121 \mathrm{C}^{\circ}$ for 45 minutes. After sterilization each bag was inoculated with one disk $(5 \mathrm{Mm})$ from the previously prepared mother culture and incubated at $25 \mathrm{C}^{\circ}$ in darkness (Wayne, 2001). Spawn bag was stored at $4 C^{\circ}$ until using (Zadrazil, 1976). Previous spawn grown on CT, VT, PD media was cultivate on rice straw which previous by serialized by steam to evaluated end product.

Treatments

- Pleurotusostreatus grows on compost tea cultivated on rice straw media

- Pleurotus ostreatus grows on vermicompost tea cultivated on rice straw media.

- Pleurotus ostreatus grows on potato dextrose cultivated on rice straw media.

- Pleurotus cystidiosus grows on compost tea cultivated on rice straw media.

- Pleurotus cystidiosus grows on vermicompost tea cultivated on rice straw media.

- Pleurotus cystidiosus grows on potato dextrose cultivated on rice straw media.

- Spawn growing on wheat grain seed cultivated on rice straw media (control).

\subsection{Measurements}

Physico-chemical determinations of compost and vermicompost and their tea were analyzed to determine the extent of stabilization according method of AOAC (2000).

Organic matter and organic carbon were determined after igniting of sample in a muffle furnace at $550^{\circ} \mathrm{c}$ for 60 minutes (Nelson and Sommers, 1996). The method described by John (1970) was used for measuring total phosphorus using spectrophotometer (Junway 2202) and total potassium by using flame photometer-128 after digesting the samples. Microbiological assays were run according to Difico manual (1985). Parasitics were determined according to Jirillo et al. (2014), seed germination percentage 
was estimated according to $\mathrm{Yu}$ et al. (2010) and nematodes were examined as mentioned by to Lenore et al. (1999). Humification parameters for assessment of organic matter stabilization in compost were also calculated:

- Humification Rate $(\mathrm{HR}) \%=\mathrm{C}(\mathrm{HA}+\mathrm{FA}) / \mathrm{TOC} \times 100$, humification index $(\mathrm{HI})=$ TC extract$\mathrm{C}(\mathrm{HA}+\mathrm{FA}) / \mathrm{C}(\mathrm{HA}+\mathrm{FA})$ and humification degree $(\mathrm{HD}) \%=\mathrm{C}(\mathrm{HA}+\mathrm{FA}) / \mathrm{TC}$ extract $\mathrm{x} 100$ (Ciavatta et al., 1990).

- Growth speed rate $=$ Colony diameter $(\mathrm{mm}) /$ Number of days from the start of growth.

- Pleurotus mushroom samples were determined for chemical composition asused by AOAC methods (AOAC, 1995).

- Protein content was determined according to the method of Leco Manuel (thermal conductivity) by the Kjeldahl method. The nitrogen factor used for protein calculation was total nitrogen $\mathrm{x}$ 6.25. (Ezeibekwe et al., 2009).

- Total Energy, fat and carbohydrate levels were determined by the method of Watt and Merrill, (1975).

- Total energy calculated as the following equation:

- Total Energy $(\mathrm{kcal} / 100 \mathrm{~g})=4 \times$ Protein $+4 \times$ Carbohydrate $+9 \times$ Fat.

- The mushroom yield was calculated according to Morais et al., (2000), using the equation: Mushroom yield $=($ Weight of fresh mushroom harvested $(\mathrm{g})$ per fresh substrate weight $)$.

- Biological efficiency percentage (BE \%) was determined according to yang et al., (2013), Stamets, (2000) and Royse et al., (2004), where, Biological efficiency \% = weight of fresh mushrooms harvested per bag / weight of dry substrate per bag $\times 100$.

\subsection{Statistical analysis:}

The randomized complete block design was used. The data were subjected to analysis of variance (ANOVA) using WASP statistical analysis software. The treatment means were separated using a Fisher's least significant difference (LSD) test. All analyses were conducted at a significance value of $\mathrm{P} \leq 0.05$ (Snedecor and Cochran, 1980.).

\section{Results and Discussion}

Compost and vermicompost are suitable for tea extract in which, their maturation degree reached to high content of organic matter (34.82 and 38.98\% respectively). Both compost and Vermicompost were free of pathogenic bacteria, parasitic, nematode and weed seeds. Vermicompost was more effecting in maturation and germination percentage (83\%), their content of humic substances, humic and fulvic acids were more than compost. The humifiction parameters in vermicompost was more higher than compost where, HI was 0.85 , humification rate $59 \%$ and humification degree $61 \%$ comprised with compost (1.1, 52 and $49.5 \%$ respectively) (Table 2 ).

Such trend of growth on mature compost was obtained by Afifi, et al. (2012) in which, the compost is mature when $\mathrm{HI}$ less than 1 and $\mathrm{HR}$ and $\mathrm{HD} \%$ more than $50 \%$.

Data in table (3) clears the overall results of biochemical composition analysis for both compost and vermicompost tea where, $\mathrm{pH}$ and electric conductivity were higher in compost tea than vermicompost tea. On the other hand, organic matter $(12.6 \%)$ in vermicompost tea was higher than compost tea as well as the content of total nitrogen, phosphorus and potassium. Proportion of total coliform, fecal coliform and salmonella and shigella bacteria were not detected either in compost or vermicompost tea.This meansthat raw compostmaterials and vermicompost are well manufactured andreached to their maturity.

The quality of compost or vermicompost tea is depended on microbial food sources, compost to water ratio, levels of aeration, degree of maturation, compost age, duration of incubation, and the quality of water used. It seems also that a good, compost tea compost tea depends on sugar or molasses to be commonly used as amendments for compost or vermicompost tea to increase its quality (Ingham, 2005). 
Table 2: Physical, chemical and biological analysis of compost and vermicompost.

\begin{tabular}{|c|c|c|c|c|c|}
\hline Type of analysis & Compost & Vermi & & Compost & Vermi. \\
\hline \multicolumn{6}{|c|}{ Physical and chemical analysis } \\
\hline Density $\left(\mathrm{kg} / \mathrm{m}^{3}\right)$ & 536 & 400 & Total nitrogen $(\%)$ & 1.3 & 1.6 \\
\hline Moisture content $(\%)$ & 18 & 27 & Organic matter $(\%)$ & 34.82 & 38.98 \\
\hline Dry matter $(\%)$ & 82 & 73 & Organic carbon $(\%)$ & 20.19 & 22.61 \\
\hline $\mathrm{pH}(1: 10)$ & 7.5 & 7.2 & Ash $(\%)$ & 65.18 & 61.02 \\
\hline $\mathrm{EC} \mathrm{dS/m}(1: 10)$ & 5.2 & 3.7 & $\mathrm{C} / \mathrm{N}$ ratio & $16: 1$ & $14: 1$ \\
\hline Ammonia (ppm) & 90 & 58 & Total phosphorus (\%) & 0.69 & 1.2 \\
\hline Nitrate (ppm) & 277 & 402 & Total potassium $(\%)$ & 0.58 & 0.89 \\
\hline \multicolumn{6}{|c|}{ Biological analysis } \\
\hline Total bacterial count ( $\left.\mathrm{cfu} / \mathrm{g} \times 10^{6}\right)$ & 60 & 120 & $\begin{array}{l}\text { Total coliform } \\
\left(\mathrm{cfu} / \mathrm{g} \times 10^{3}\right)\end{array}$ & nd & nd \\
\hline Total actinomycets $\left(\mathrm{cfu} / \mathrm{g} \times 10^{4}\right)$ & 12 & 10 & Faecal coliform $\left(10^{3}\right)$ & nd & nd \\
\hline Total fungi (cfu/g x10 $\left.0^{4}\right)$ & 9 & 13 & $\begin{array}{l}\text { Salmonella } \& \text { Shigella } \\
\left(\mathrm{cfu} / \mathrm{g} \times 10^{3}\right)\end{array}$ & nd & nd \\
\hline Nematode (larva/200g) & nd & nd & Weed Seeds & nd & nd \\
\hline Parasitic & nd & nd & Germination percentage & 78 & 83 \\
\hline \multicolumn{6}{|c|}{ Humifiation parameters } \\
\hline Humic index (HI) & 1.1 & 0.85 & Humic substances\% & 19 & 27 \\
\hline Humification rate \% (HR) & 52 & 59 & Humic acid \% & 10.5 & 18.6 \\
\hline Humification degree \% (HD) & 49.5 & 61 & Fulvic acid $\%$ & 8.1 & 8.2 \\
\hline
\end{tabular}

Vermini. : Vermicompost; nd: not detected; C/N: Carbon / Nitrogen ratio; cfu: colony forming unit

Table 3: Chemical and biological determinations on compost and vermicompost tea

\begin{tabular}{|c|c|c|}
\hline Type of analysis & Compost tea & Vermicompost tea \\
\hline \multicolumn{3}{|c|}{ Chemical analysis } \\
\hline pH & 6.96 & 8.05 \\
\hline $\mathbf{E C}(\mathbf{d S} / \mathrm{m})$ & 4.96 & 2.70 \\
\hline Organic matter (\%) & 8.8 & 12.6 \\
\hline Organic-Carbon $(\%)$ & 5.14 & 7.3 \\
\hline $\mathrm{N}-\mathrm{NH}_{4}^{+}(\mathbf{p p m})$ & 93 & 8.0 \\
\hline $\mathrm{N}^{-\mathrm{NO}_{3}^{-}}{ }_{3}(\mathrm{ppm})$ & 115 & 36 \\
\hline Total-N(ppm) & 369 & 810 \\
\hline Available-P(ppm) & 88 & 11200 \\
\hline Available-K(ppm) & 118 & 13200 \\
\hline \multicolumn{3}{|c|}{ Biological determination (cfu/ml) } \\
\hline Total coliform & nd & nd \\
\hline Fecal coliform & nd & nd \\
\hline Salmonella and shigella & nd & nd \\
\hline
\end{tabular}

nd: not detected. organic matter and total nitrogen determined as dry basis.

Comparing the growth weight (mycelium) (Table. 4) Pleurotus ostreatus was greater than Pleurotus cystidiosus in all treatments. Vermicompost tea agar media has as an significant value compared to other media where, it obtained 23.7 and $13.3 \mathrm{~g}$ with both species after incubation periods (21 days) respectively, Meanwhile, it revealed that the lowest effect of colony diameter $(4.9 \mathrm{~mm})$ with Pleurotus ostreatus. On the other hand, CTA media presented the lowest weight with Pleurotus ostreatus $(8.3 \mathrm{~g})$, whereas, PDA in media was not the same value. Also, the growth of Pleurotus cystidiosus species $(7.7 \mathrm{~g})$ was not pronounced in PDA medium. The spread of colonies (colony diameter) of Pleurotus cystidiosus on petri-dishes in PDA media produced for growth gave only $8.2 \mathrm{~g}$, while CTA media was the lowest $(6.7 \mathrm{~g})$. The result in Tab. 4 revealed that the growth speed rate with both Pleurotus ostreatus and Pleurotus cystidiosus has high rate in PDA media (0.38 and 0.39 respectively).

Figures 1 and 2 showed that both pleurotus species were well grown in differentliquid media (potato dextrose, vermicompost tea and compost tea) before the propagation of two types on rice straw. 
Table 4: Weight, colony diameter and growth spread rate for two species of pleurotus after the incubation period (21 days).

\begin{tabular}{lcccccc}
\hline Mean \pm SE & \multicolumn{2}{c}{ Pleurotus ostreatus } & \multicolumn{3}{c}{ Pleurotus cystidiosus } \\
\cline { 2 - 7 } \multicolumn{1}{c}{ Types of media } & $\begin{array}{c}\text { Weight } \\
\mathbf{( g )}\end{array}$ & $\begin{array}{c}\text { Colony } \\
\text { Diameter } \\
\mathbf{( M m )}\end{array}$ & $\begin{array}{c}\text { Growth Speed } \\
\text { Rate }\end{array}$ & $\begin{array}{c}\text { Weight } \\
\mathbf{( g )}\end{array}$ & $\begin{array}{c}\text { Colony } \\
\text { Diameter } \\
\text { (mm) }\end{array}$ & $\begin{array}{c}\text { Growth } \\
\text { Speed } \\
\text { Rate }\end{array}$ \\
\hline Potato dextrose Agar & $13.6 \mathrm{~b}$ & $7.9 \mathrm{a}$ & 0.38 & $7.7 \mathrm{c}$ & $8.2 \mathrm{a}$ & 0.39 \\
Vermicompost tea agar & $23.7 \mathrm{a}$ & $4.9 \mathrm{c}$ & 0.23 & $13.3 \mathrm{a}$ & $7.9 \mathrm{ab}$ & 0.38 \\
Compost tea agar & $8.3 \mathrm{c}$ & $7.3 \mathrm{ab}$ & 0.35 & $8 \mathrm{~b}$ & $6.7 \mathrm{c}$ & 0.32 \\
LSD (0.05) & 0.501 & 0.227 & & 0.2978 & 0.2599 & \\
\hline
\end{tabular}

Means followed by the same letter (s) within a column in each block are not significantly different $(\mathrm{P} \leq 0.05)$.

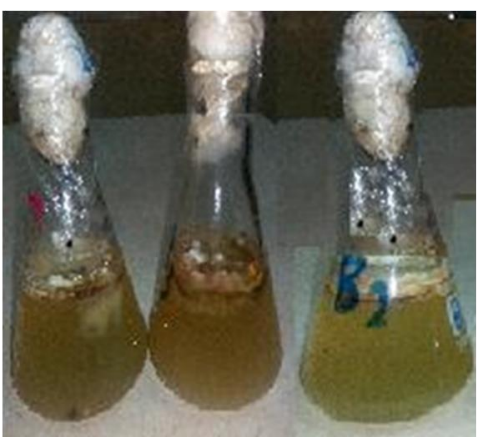

Potato dextrose

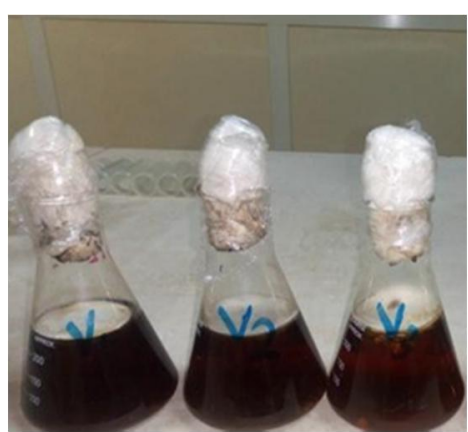

Vermicompost tea

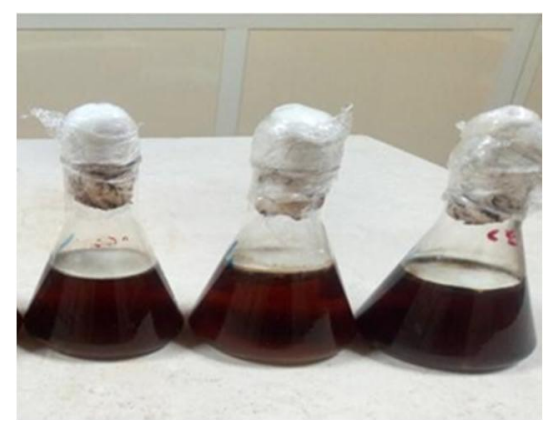

Compost tea

Fig. 1: Show Pleurotus ostreatus grows on different liquid media.

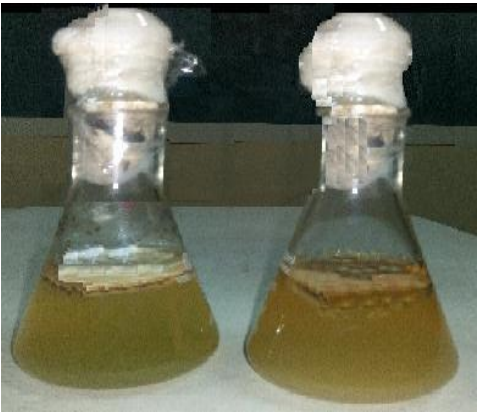

Potato dextrose

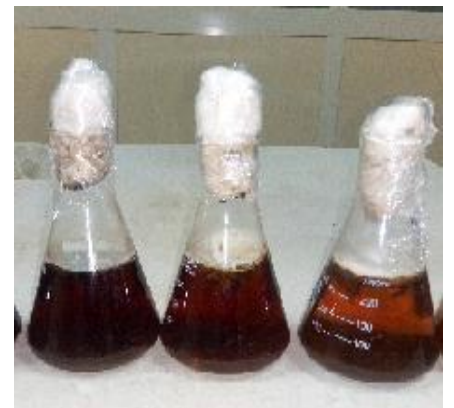

Vermicompost tea

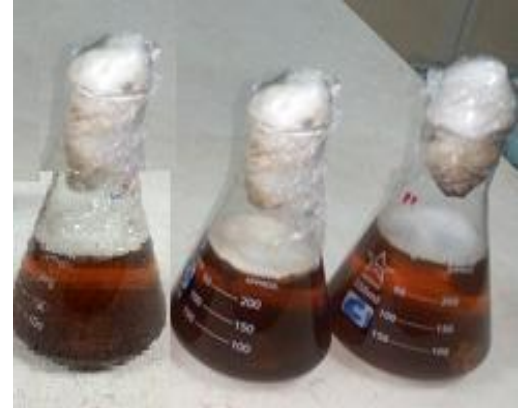

Compost tea

Fig 2: Show Pleurotus cystidiosu grows on different liquid media.

Various liquid media inoculated on rice straw as traditional media to evaluate the best growth for pleurouts production. The production was achieved from numbers of picks (four picks). The first pick of Pleurouts cystidiosus was after 21 days of incubation period on rice straw media also fifteen days were followed between each pick (second, third and fourth pick). In these respect Pleurotusostreatus gave total yield more than Plourotus cystidiosus with all media, vermicompost tea media was more superior for all treatments where, achieved $9.95 \mathrm{Kg}$ more than control. Moreover, the Pleurotus ostreatus which has grown on wheat seeds was in the second rank $(8.6 \mathrm{Kg})$. Meanwhile, compost tea of the third rank obtained $6.75 \mathrm{Kg}$, while, Pleurotus ostreatus which grown on potato dextrose media, produced about $(5 \mathrm{Kg})$ (Table 5) and figure (3).

Table 5: Weight (Kg) of Pleurotus ostreatus during incubation period (3 months)

\begin{tabular}{lccccc}
\hline \multicolumn{1}{c}{ Numbers of picks } & Pick & Pick & Pick & Pick & Total \\
Types of media & $(\mathbf{1})$ & $\mathbf{( 2 )}$ & $\mathbf{( 3 )}$ & $\mathbf{( 4 )}$ & weights \\
\hline Wheat seeds (control) & 2.25 & 2.5 & 2.3 & 1.5 & 8.55 \\
Vermicompost tea & 2.5 & 2.6 & 2.6 & 2.25 & 9.95 \\
Compost tea & 2 & 2 & 1.5 & 1.25 & 6.75 \\
Potato dextrose & 1.7 & 1.5 & 1.3 & 0.5 & 5 \\
\hline
\end{tabular}




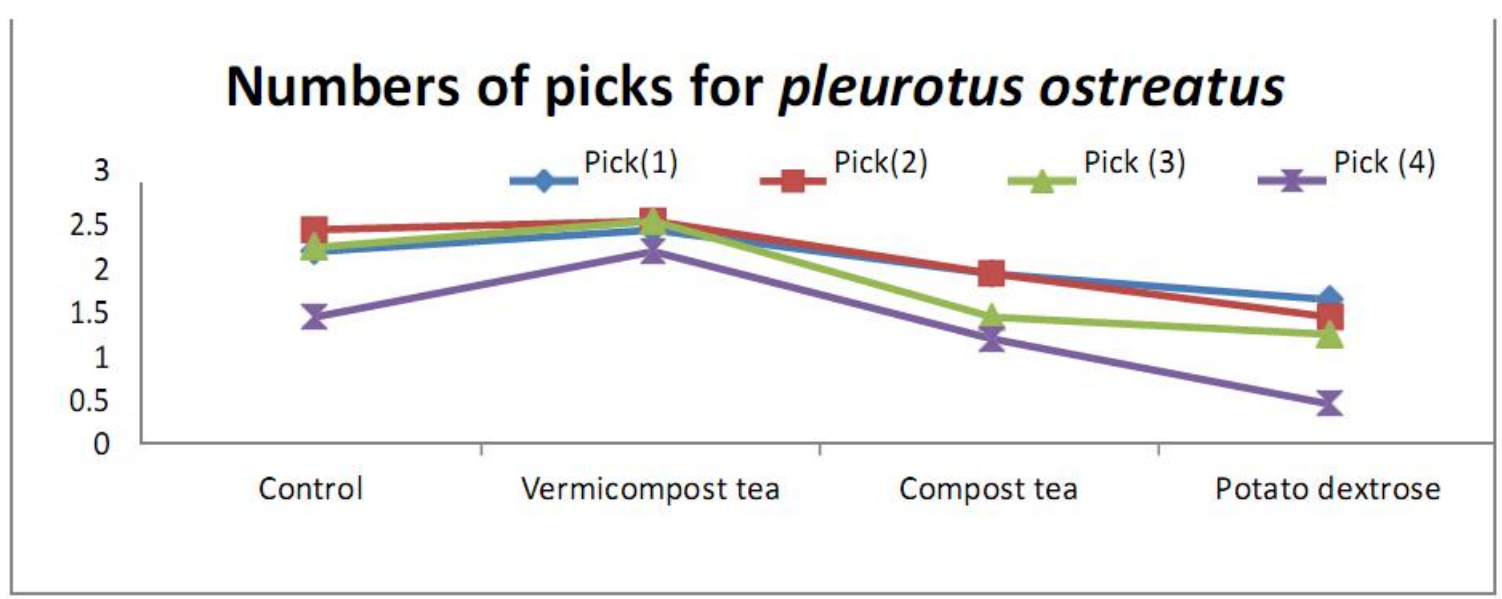

Fig. 3: Number of picks for pleurotus ostreatus

It worth to mention, that the period of picks continues from three to four days from the beginning to get the primary fruits until all growth was picked. Also, it should be noted that, the Plourotus cystidiosus which has grown on vermicompost tea media was successfully proportioned than other treatments in total picks after three months $(7.5 \mathrm{Kg})$. The content of organic matter, total nitrogen, phosphorus and potassium in vermicompost tea media were greater than the other media. Meanwhile, the growth of Pleurotus cystidiosus has on wheat seed media (control) followed by vermicompost tea media where the total weight reached to $7 \mathrm{~kg}$. On the other hand, the pleurouts which grown on potato dextrose produced only $3.5 \mathrm{~kg}$ (Table (6) and figure (4).

Table 6: Weight (Kg) of Pleurotus cystidiosus during incubation period (3 months)

\begin{tabular}{lccccc}
\hline \multicolumn{1}{c}{ Number of picks } & Pick & Pick & Pick & Pick & Total \\
Types of media & $(\mathbf{1})$ & $\mathbf{( 2 )}$ & $\mathbf{( 3 )}$ & $\mathbf{( 4 )}$ & weights \\
\hline Wheat seeds (control) & 2.5 & 2.5 & 1.5 & 0.5 & 7.0 \\
Vermicompost tea & 2.25 & 2.0 & 2.0 & 1.25 & 7.5 \\
Compost tea & 1.5 & 1.5 & 1.0 & 0.5 & 4.5 \\
Potato dextrose & 1.5 & 1 & 1 & -- & 3.5 \\
\hline
\end{tabular}

\section{Number of picks for pleurotus cystidiosus}

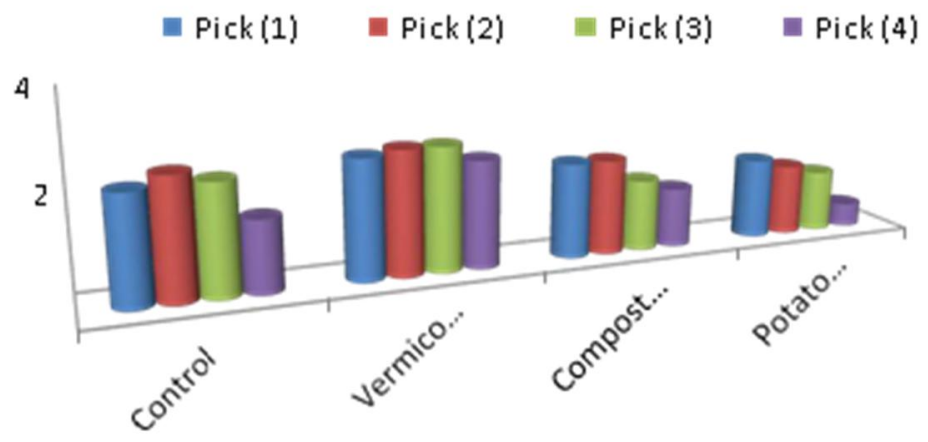

Fig. 4: Numbers of picks for pleurotus cystidiosus

Generally, the result revealed that mushroom weight of two species (pleurotus cystidiosus and ostreatus grown on various substrate types was significantly different. It is obvious to note that the Pleurotus species which grown on vermicompost with cotton waste and soil has the lowest yield and poor quality of mushroom. (Yadavet al., 2017).

Spawn production (Tab. 7) of pleurotus ostreatus cultivated in VT on rice straw achieved the 
highest content of total protein, fat and ash 27.3, 2.3 and 6.85 respectively. This may be due to the high content of different macro elements as well as organic matter was in vermicompost with compost tea. While spawn which grown on wheat seed media (control) contained more total carbohydrates and energy (55.3 and $312.9 \mathrm{kcal} / 100 \mathrm{~g}$ respectively). Such results were also found when different species of mushroom were grown on various media (NurAziera et al., 2015). In these respect, different biochemical values were overall trend to produce low carbohydrate content.

Table 7: Effect of different substrate formulas on nutritional composition of Pleurotus ostreatus mushroom.

\begin{tabular}{lcccccccc}
\hline \multirow{2}{*}{ Type of media } & \multicolumn{3}{c}{ Macronutrients (\%) } & \multicolumn{5}{c}{ Total (\%) } \\
\cline { 2 - 8 } & Nitrogen & phosphorus & Potassium & Carbohydrate & Proteins & Fat & Ash & $\begin{array}{c}\text { Energy } \\
\text { (kcal/100 g) }\end{array}$ \\
\hline $\begin{array}{l}\text { Wheat seeds } \\
\text { Compost tea }\end{array}$ & 2.9 & 0.95 & 1.5 & 55.3 & 18.65 & 1.9 & 5.3 & 312.9 \\
$\begin{array}{l}\text { Vermicompost } \\
\text { tea }\end{array}$ & 4.0 & 1.5 & 2.3 & 32.4 & 25.30 & 2.1 & 6.2 & 249.7 \\
$\begin{array}{l}\text { Potato } \\
\text { dextrose }\end{array}$ & 1.4 & 2.8 & 39.2 & 27.30 & 2.3 & 6.8 & 286.7 \\
\hline
\end{tabular}

Total yield and biological efficiency (BE) were used to measure the efficiency of mushroom (Pleurotus cystidiosus and Pleurotus ostreatus) to produce their yield from the given substrate (Tajdeen et al., 2012). Results in table (8) reveled that Pleurotus ostreatus grown on vermicompost tea media gave higher yield of mushroom and $\mathrm{BE} \%$ than other treatments and the wheat seeds (control) where it achieved $9950 \mathrm{~g}$ and $156.25 \%$ respectively. The results indicated also that potato dextrose media produced low total yield and BE\% (5000g and 72.91\% respectively).

Table 8: Total yield and biological efficiency (BE) of Pleurotus ostreatus on different media.

\begin{tabular}{lcc}
\hline Types of media & $\begin{array}{c}\text { Total yield of mushrooms } \\
\text { (g) }\end{array}$ & $\begin{array}{c}\text { Biological efficiency } \\
\text { (BE } \%)\end{array}$ \\
\hline wheat seeds (control) & 8550 & 145.83 \\
Vermicompost tea & 9950 & 156.25 \\
Compost tea & 6750 & 93.75 \\
Potato dextrose & 5000 & 72.91 \\
\hline
\end{tabular}

The growth of Pleurotus cystidiosus on vermicompost tea media was more pronounced in total yield $(8200 \mathrm{~g})$ and biological efficiency $(150 \%)$ compared with other treatments as well as the control treatment (Table 9). Similar results were obtained by Obodai and Vowotor (2003), but higher than some other report, which has also relatively well yields and BE (Zhang et al., 2002).

Table 9: Total yield of and biological efficiency of Pleurotus cystidiosus on different media

\begin{tabular}{lcc}
\hline Types of media & Total yield of mushrooms (g) & Biological efficiency (BE \%) \\
\hline Wheat seeds (control) & 7440 & 122.70 \\
Vermicompost tea & 8200 & 150 \\
Compost tea & 6750 & 90.62 \\
Potato dextrose & 4500 & 59.20 \\
\hline
\end{tabular}

\section{References}

Afifi, M.M.I., A.N. Estefanous and Y.S. El-Akshar, 2012. Biological, Chemical and Physical Properties of Organic Wastes as Indicators Maturation of Compost. Journal of Applied Sciences Research, 8(4): 1857-1869.

Antonio G.F., C.R. Carlos, R.R. Reiner, A.A. Miguel , O.L.M. Angela, M.J.G. Cruz and L. Dendooven, 2008. Formulation of a liquid fertilizer for sorghum (Sorghum bicolour (L.) Moench) using vermicompost leachate. Bioresour. Technol. 99: 6174-6180.

AOAC, 1995. Official methods of the Association of Official Analytical Chemists, sixteenth ed. Association of Official Analytical Chemists, Arlington, VA. 
AOAC., 2000. Horwitz W (ed) Official Methods of Analysis of AOAC International. 17 $7^{\text {th }}$ ed. Gaitheresburg, Maryland. 3. Arillo A, Melodia F (1991) Reduction of hexavalent chromium by the earthworm E. fetida (Savigny).Ecotoxicol. Environ. Saf. 57: 391- 394.

Bahl, N., 1998. Hand book on mushrooms. Oxford\& IBH Publishing co Pvt Ltd.pp.15-40.

Booth, C., 1971. Methods in microbiology. Mycological society.4: 597 London.

Chang, S.T., 1991. Cultivated mushrooms. In: Handbook of Applied Mycology, 3: 221-240. Marcel Dekker, New York.

Chang, S.T., 1999.World production of cultivated and medicinal mushrooms in 1997with emphasis on Lentinus edodes. International Journal of Medicinal Mushrooms.1: 291 - 300.

Civatta, C., M. Govi, A. Vittori, and P. Sequi, 1990. Characterization of humified compounds by extraction and fractionation on solid polyphnilpyrrolidone. J. Chromatogr., 509: 141-146.

Das, N. and M. Mukherjee, 2007. Cultivation of Pleurotus ostreatus on weed plants. Bio Resource Technology 98: 2723 - 2726.www.science direct.com retrieved on07/08/2007.

Difco, M., 1985. Dehydrated culture media and reagents for microbiology.

Laboratories Incorporated Detroit. Michigan 48232, USA, 621.

Eswaran, A. and R. Ramabadran, 2000. Studies on some physiological, cultural and postharvest aspects of oyster mushroom, Pleurotus ostreatus. Tropical Agricultural Research.12: 360 -374.

Ezeibekwe, I.O., C.I. Ogbonnaya, C.I. Unamba and O.M. Osuala, 2009. Proximate analysis and mineral composition of edible mushrooms in parts of South Eastern Nigeria. Rep Opin, 1:32-36.

Ingham E.R., 2005. The Compost Tea Brewing Manual, fifth ed.US Printings, Soil Food web Incorporated, Oregon.

Jirillo, E., T. Magrone, and G. Miragliotta, 2014. Immuno modulation byParasitic Helminths and its Therapeutic Exploitation. In: Pineda, M.A., Harnett, W. (Eds), Immune Response to Parasitic Infections (Vol 2, pp 175-212), Bentham eBooks, DOI:10.2174/97816080598501140201.

John, M.K., 1970. Colorimetric determination of phosphorus in soil and plant material with ascorbic acid. Soil Sci 109:214-220.

Lenore S.C., E.G. Arnold and D.E. Andrew, 1999. Standard methods $20^{\text {th }}$ edition for the examination of water and wastewater. Copyright 1999 by American Public Healt Association (APHA), American Water Works Association (AWWA), Water Environment Federation (WEF).

Morais, M.H., A.C. Ramos, N. Matos, and E.J. Oliveira, 2000. Note: Production of shiitake mushroom (Lentinus edodes) on ligninocellulosic residues. Food Science and Technology International, 6 (2): 123-128.

Nelson, D.W. And L.E. Sommers, 1996. Total carbon and organic carbonand organic matter. In: Page AL, Miller RH, Keeney DR (ed) Method of Soil Analysis. American Society of Agronomy, Madison, Wilcosin, 539-579

NurAziera, A., Z. Zarina, F. Mohammad, A. Ridzwan and O. Hakimah, 2015. Characterization of biochemical compostion for different types of spent mushroom substrate in Malaysia. Malaysian Journal of Analytical Sciences, 19 (1): $41-45$.

Obodai, M.C.O. and K.A. Vowotor, 2003. Comparative study on the growth and yield of Pleurotus ostreatus mushroom on different lignocellulosic by- products. J. Ind. Microb. J Ind Microbiol Biotechnol Mar; 30(3):146-9.

Oei, P., 2003. Mushroom cultivation, appropriate technology for mushroomgrowers. Netherlands. 1084.

Pavlik, M., 2005.Growing of Pleurotus ostreatus on woods of various deciduous trees, ActaEdulis Fungi, 12: 306-312.

Rahman, N.A., F.S. Daud, M. Kalil, and S. Ahmad, 2012. Wseast transactions on Biology and Biomedicine.issue 3(9): 2224-2902.

Royse, D.J., T.W. Rhodes, S. Ohga, and J.E. Sanchez, 2004. Yield, mushroom size and time to production of Pleurotus cornucopiae (oyster mushroom) grown on switch grass substrate spawned and supplemented at various rates. Bioresource Technology, 91(1): 85-91.

Royse, D.J., 2002. Influence of spawn rate and commercial delayed release of nutrient levels on Pleurotus conocopiae yield, size and time to production. Applied Microbiology and Biotechnology.17: $191-200$.

Shrestha A.K., and F. Mizutani, 2013. Influence of organic mulches on fruit quality, soil nutrition and weed control in `Miyauchiyo. Green Farming, 4 (1): 109- 114. 
Tajudeen O., S. Swazi, K. Paul, T. Michael, and M. Diana, C. Vanderzant, and D. Splittstoesser, 2012. Effect of Wheat Bran Supplement on Growth and Yield of Oyster Mushroom (Pleurotus Ostreatus) on Fermented Pine Sawdust Substrate. Experimental Agriculture \& Horticulture SSNs: 1929-0861; 1929-087X@ Academic Research Centre of Canada.

Vanderzant, C., and D.F. Splittstoesser, 1992. Compendium of methods for the microbiological examination of food, $3^{\text {rd }}$ ed. American Public Health Association, Washington, D.C.

Watt, B.K. and A.L. Merrill, 1975. Composition of foods: raw, processed, prepared, Agriculture Handbook No. 8. Science Education Administration, USDA

Snedecor, G.W. and W.G. Cochran, 1980. Statistical Method, $7^{\text {th }}$. The Iowa State University Press, Ames., Iowa USA., 504.

Stamets, P., 2005. Mycelium running, how mushrooms can help save the world. Ten speed press, Berkeley, Toronto, Canada. 339pp

Stamets, P. and J. Chilton, 1983. A practical Guide to Growing Mushroom at Home. Agarikn Press. Olympia, Washington, US. 415.

Stamets, P., 2000. Growing Gourmet and Medicinal Mushrooms ( $3^{\text {rd }}$ ed., pp. 1- 574). Berkley: Ten Speed.

Sylvia E.W., 2004. The effect of compost extract on the yield of strawberries and Severity of Botrytis cinerea. J. Sustainable Agric.25. Bioresource Technology 102, 8027-8034., Washington, D.C.

Wayne, R.R., 2001. Growing mushroom the easy way. Mushroom science. 1: 37.

Yadav, M.K., C. Ram, S.K. Yadav, P.K. Dhakad, A.K. Srivastava, P.K. Dwivedi, and N. Sushreeta, 2017. Comparative evaluation of locally available casing materials for quantitative and qualitative effect on two strains of Agaricus bisporus (lange). Biochem. Cell. Arch., 17 (1): 133-139.

Yang, W.J., F.L. Guo, and Z.J. Wan, 2013. Yield and size of oyster mushroom grown on rice/wheat straw basal substrate supplemented with cotton seed hull. Saudi J. Biol. Sci. 20: 333-338.

Yu, G.H., Y.H. Luo, M.J. Wu, Z. Tang, D.Y. Liu, X.M. Yang, and Q.R. Shen, 2010. PARAFAC modeling of fluorescence excitation-emission spectra for rapid assessment of compost maturity.Bioresour. Technol., 101: 8244-8251.

Zadrazil, F., 1976. The ecology and industrial production of Pleurotus ostreatus, P. florida, $p$. cornucopiae, and p. eryngii. Mushroom science. 1: 621-652.

Zhang, R.H., X.J. Li, and J.G. Fadel, 2002. Oyster mushroom cultivation with rice and wheat straw. Bioresour. Technol. 82: 277-28. 